\title{
POSSIBLE LIQUID IMMISCIBILITY TEXTURES IN HIGH-MAGNESIA BASALTS FROM THE VENTERSDORP SUPERGROUP, SOUTH AFRICA ${ }^{1}$
}

\author{
R. GRANT CAWTHORN, J. R. MCIVER, T. S. MCCARTHY B. A. WYATT2 ${ }^{2}$ \\ J. FERGUSON ${ }^{3}$ AND SARAH J. BARNES 4 \\ Geology Department, University of the Witwatersrand, Johannesburg 2001, South Africa
}

\begin{abstract}
The lowermost succession of Javas in the Proterozoic Ventersdorp Supergroup contains Jight weathering ocelli up to $15 \mathrm{~cm}$ in diameter which occur in layers of a darker weathering volcanic material. Sorne ocelli appear to merge, and discrete light weathering layers may be the ultimate end-stage of this coalescence. Alternatively, coexisting magmas in the neck of the volcano may have been erupted in varying proportions, and turbulence during fiow caused spalling of large drops of the Jighter weathering material into the other. Severa) lines of field evidence suggest that two distinct liquids coexisted and were rapidly quenched after eruption. Chemical data for ocelli and matrix are consistent with the hypothesis of liquid immiscibility. The differences in compositions between the coexisting pairs of liquids are small and it is suggested that the original magmas must have been close to the consulute composition.
\end{abstract}

\section{INTRODUCTION}

The hypothesis of silicate-silicate liquid immiscibility in lavas and intrusive igneous bodies for the production ofliquids of differing composition has always been overshadowed by ideas of fractionation. Silicate-sulphide and silicatecarbonate immiscibility occur readily for appropriate compositions and are easily recognisable; but silicate-silicate separation usually produces Jess definitive features. Philpotts (1976) has discussed the examples of silicatesilicate immiscibility from an originally silicaundersaturated magma. A second type of magma from which separation may occur is iron-rich tholeiitic liquid. Roedder and Weiblen (1971) and De (1974) reported lavas with immiscibility textures, while McBirney and Nakamura (1974) suggested that immiscibility may produce some of the granophyres of the Skaergaard intrusive complex of Greenland. Lunar analogues have been reported by Roedder and

${ }_{1}^{1}$ Manuscript received April 27, 1978; revised September 8, 1978.

2 Presently at Anglo-American Research Laboratories, Crown Mines 2093, Transvaal, South Africa.

3 Presently at Bureau of Minerai Resources, P.0. Box 378, Canberra City, Australia.

4 Presently at Geological Survey, Windhoek 9100, South West Africa.

[JouRNAL OF ÜEOLOGY, 1979, Vol. 87, p. 105-113]

(C) 1979 by The University of Chicago.

0022-1376/79/8701-0009\$0:88
Weiblen (1970) and Hess et al. (1975). In ail these cases immiscibility occurred only after extensive fractionation of the basaltic parent. Gélinas et al. (1976) suggested immiscibility may occur in unfractionated tholeiitic magmas and Drever (1960) and Ferguson and Currie (1972) suggested that immiscibility may occur in picritic magmas. Liquid immiscibility may be possible, therefore, for a wide range of liquid compositions.

A most spectacular example of what we believe to be liquid immiscibility may be seen in a quarry $10 \mathrm{~km}$ south of Johannesburg. In this communication, the physical appearance of these unusual rocks is documented, and some chemical evidence bearing on their origin by Iiquid immiscibility is presented.

\section{FIELD RELATIONS}

The material to be described cornes from the base of the Ventersdorp Supergroup which represents a widespread cratonic accumulation, dominated by Iow-magnesia tholeiitic eruptives together with lesser tuffaceous and agglomeratic materials, acid lavas and sediments, the detailed succession of which has been documented by Winter (1976) who considered it to be between 2.5-2.7 b.y. Its distribution is confined to the west central portions of South Africa and eastern Botswana (see fig. 1).

Immediately south of Johannesburg the Iowermost Ventersdorp eruptives overlie the sedi- 


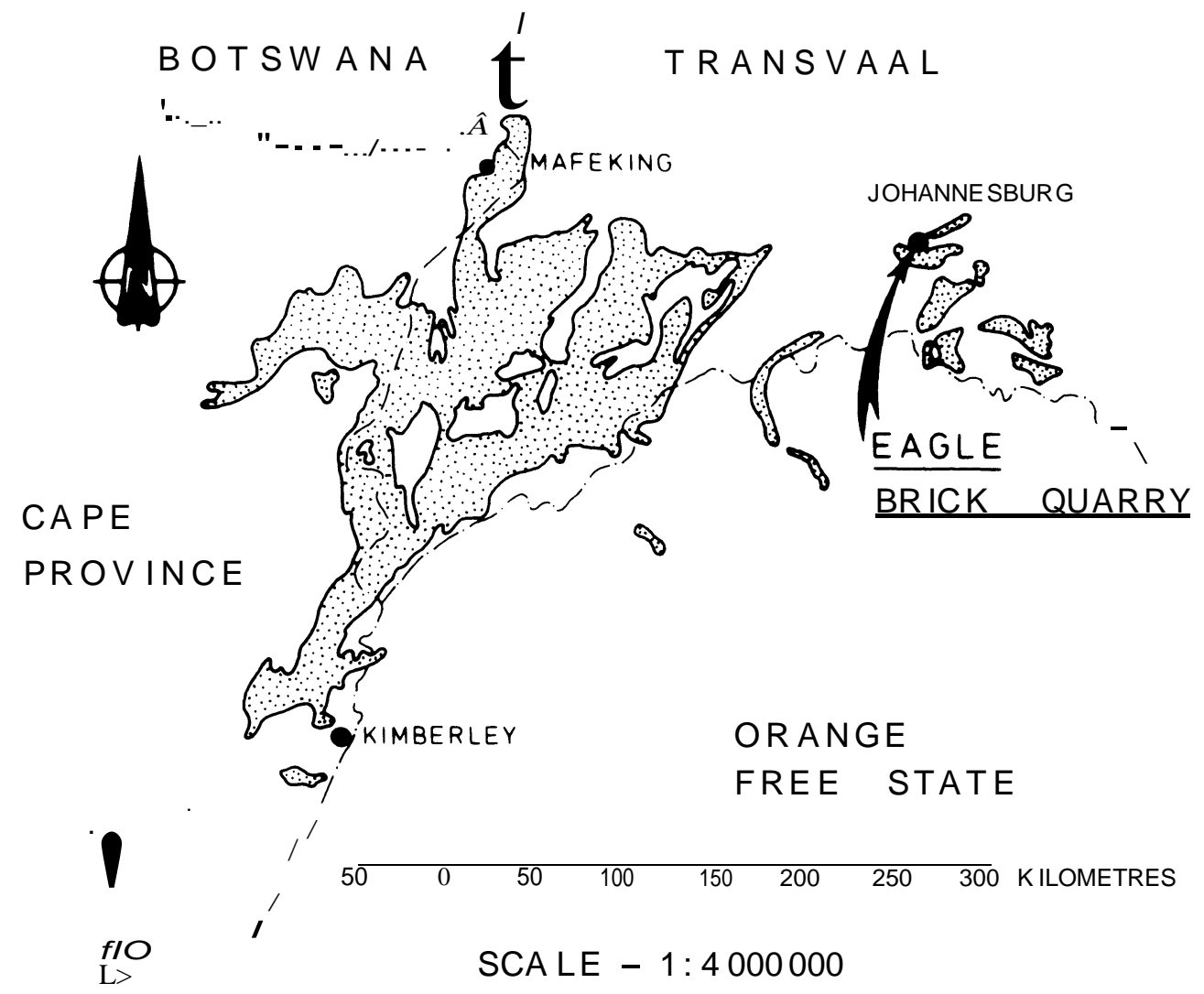

Fm. 1.-Locality map, showing the area of southern Africa, underlain by the Ventersdorp Supergroup (after Truswell, 1970).

ments of the Witwatersrand Supergroup with an apparently conformable relationship. The lowermost portion of the sequence is made up of a succession of amygdaloidal high-magnesia basaltic rocks which do not exceed $80 \mathrm{~m}$ in thickness and which contrast markedly in composition with the volumetrically more abundant overlying low-magnesia basaltic rocks (Wyatt 1976). To date, the high-magnesia basalts have only been recognized in a limited area south of Johannesburg, but it is thought possible that talcose tuffs occurring elsewhere at the base of the Ventersdorp sequence (Winter 1976) could represent less well preserved equivalents of these rocks.

A section of the high-magnesia basait succession is exposed to advantage in a quarry exploited by Eagle Brick and Tile Co. (Pty) Ltd. on the northern ftank of the Klipriviersberg Range where stripping of clay has exposed a rock face some $150-200 \mathrm{~m}$ long by $12 \mathrm{~m}$ high. The basait exposures take the form of a series of southward dipping $\left(15-20^{\circ}\right)$ composite units usually made up of a lower dark colored portion capped by a light colored layer. The exposed face contains nine such composite lava ftows with individual units having thicknesses of 0.5-2 m, each unit displaying remarkable constancy of thickness over the whole quarry face. A measured section is shown in figure 2. Generally, thicker dark layers have better developed light layers associated with them, but no constant relationship between thickness of dark and light layers could be established. The upper contacts of the light layers are relatively planar and sharply defined. Lower surfaces of the light 



FIG. 2.-Measured section of the quarry face with the light (L) and dark (D) weathering horizons, positions of ocelli (black circles) and distribution of amygdales (Am.-small irregular shapes) indicated. Note the lower half of the section (on left) is on a di!Terent scale from upper half.

layers frequently show cuspate convolutions. No evidence of lava-top characteristics was observed.

Globular structures in the form of ocelli of light colored basait within dark basait are most abundant in units Jess than $1.0 \mathrm{~m}$ thick. Photographs of these textures have been presented by Cawthorn and McCarthy (1977). Laterally, the distribution of the ocelli is erratic. In the vertical sense the ocelli are invariably concentrated in the upper third of the dark layers with the greatest concentration occurring immediately below the light layer. Not all the dark layers, however, contain these ocelli. Apparent fusion of some ocelli on to the bottom of the light layers gives rise to hemispherical forms which appear to merge completely with the lightcolored portion of the basait unit and often produces a cuspate contact. The overall range of diameters of the ocelli is $1.0-15.0 \mathrm{~cm}$. No relation exists between the thickness of a dark colored layer and the size of the ocelli present. In one $20 \mathrm{~cm}$ thick dark layer ocelli up to $10 \mathrm{~cm}$ in diameter are present. Although the entire sequence contains an abundance of amygdales, little upward concentration of these structures is apparent thus suggesting rapid chilling of the lavas which could have prevented escape or upward movement of entrapped gas.

Philpotts (1977) has suggested several texturai and field relations which are to be expected of immiscible liquids. He concluded (p. 140) that "interfacial tension between liquids will not permit the persistence of sharply curved boundaries" where two ocelli begin to coalesce. In figure 3 , it can be seen that two spheres are in the process of coalescing and that they are both merging into the light colored cuspate layer. Despite the extremely sharp contacts between ocelli and matrix the internai contacts between the ocelli and with the light layer have disappeared as predicted by Philpotts (1977). Using 


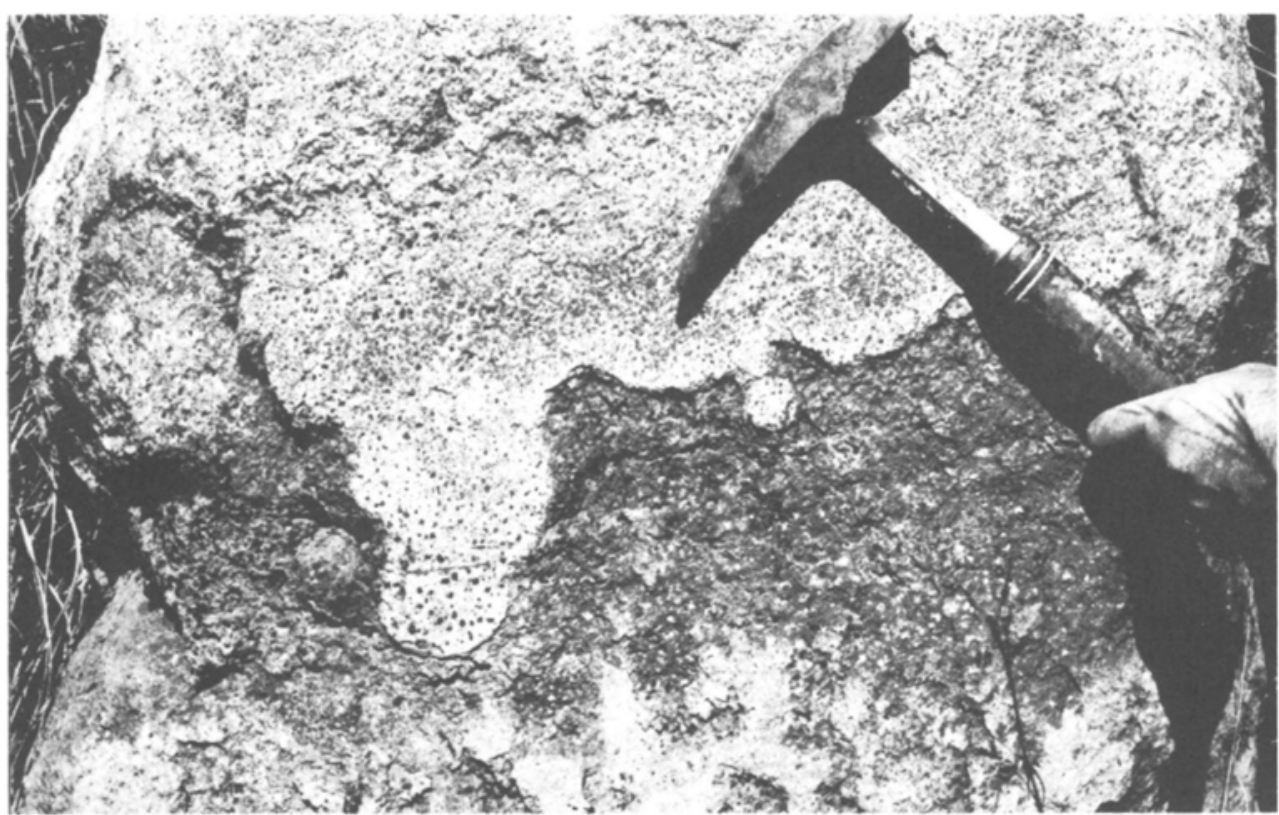

FIG. 3.-Detail oflower contact of light weathering layer. One large ocellus bas merged with the layer and a slightly smaller ocellus bas merged into the larger one. Note the absence of internai contacts between ocelli and layers where they have merged.

experimental charges as a guide, Philpotts (1977) suggested that if large ocelli were generated in a subvolcanic environment small ocelli ought to be produced on eruption, thus generating a pronounced bimodal sizedistribution. We have not observed this feature, perhaps as a result of rapid cooling from a viscous magma, but we have found one example of a relatively small $(1 \mathrm{~cm})$ ocellus present inside a larger $(10 \mathrm{~cm})$ ocellus. This suggests that exsolution was continuing with cooling.

\section{PETROGRAPHY}

The basalts have been significantly altered by greenschist facies metamorphism. Mineralogically the ocelli and light horizons are similar. Their major constituent is a fine-grained irregularly shaped felted assemblage of stubby tremolite and chlorite crystals with very diffuse edges set in a sparse indeterminate fine-grained matrix which possibly represents altered devitrified volcanic glass. Small disseminated pyrite crystals are frequently encountered in both ocelli and light horizons and, in both, amygdales are filled with chalcedony together with minor calcite and chlorite. The dark colored layers have a similar mineralogy and differ only in that chlorite is somewhat more abundant than in the light horizons. Amygdales are filled essentially by chlorite accompanied by lesser carbonate. Spherulitic textures have been attributed to devitrification processes, as suggested by Hughes (1977) in his discussion of the observations of Gélinas et al. (1976). We can reject this mechanism for this study because of the presence of amygdales throughout the ocelli.

\section{MECHANISM OF EMPLACEMENT}

Nowhere in the very limited exposure of these rocks is there any evidence of the volcanic center which produced these lavas. The lateral uniformity of these lavas suggests that individual flows cover very wide areas and were produced by a fluid lava flowing over a very fiat topography. Despite their wide coverage, the presence of gas cavities frozen into the lava throughout the entirity of nearly every flow 
suggests fairly rapid cooling. It would seem rather anomalous, therefore, to invoke a process of liquid immiscibility producing two liquids with a density difference in the order of $0.5 \mathrm{gm} / \mathrm{cc}$ determined from the compositions using the equations of Bottinga and Weill (1970) and an average viscosity difference of a factor of 4.5, using the method of Bottinga and Weill (1972) which managed to separate, and

the lighter material to rise upwards to form layers, while gas bubbles were trapped in the lavas. The Jack of correlation between thickness of adjacent dark and light layers and size of globules to thickness of flow also seems surprising if liquid immiscibility occurred after eruption. The extreme size of these ocelli also argues against their rapid formation.

The physical separation of the two magmas may have occurred in the neck of the volcano prior to eruption, where a large body of magma would not cool quickly, but remain liquid long enough for the development ofliquid immiscibility and possibly the formation of two layers of immiscible liquid. Any belch of lava coming from this magma chamber could incorporate variable proportions of the two liquids and any turbulence and convection in this erupted mixture could produce spheres of light material being tom from the contact of the two magmas and being tumbled around within the dark layers.

\section{CHEMISTRY}

Seventeen pairs of analyses have been obtained, eight of which have been published elsewhere (Cawthorn and McCarthy 1977). Samples were obtained by taking very thin slices of rock and carefully chiselling out ocellus and matrix, and analyses were performed by conventional X-ray fluorescence techniques.

For sixteen of the seventeen pairs ofanalyses certain patterns emerge (fig. 4 ). $\mathrm{SiO}_{2}$ is higher in the ocellus than the matrix, while $\mathrm{MgO}, \mathrm{FeO}$ (total), $\mathrm{CaO}$ and $\mathrm{TiO}_{2}$ show lower values. $\mathrm{Al}_{2} \mathrm{O}_{3}$ does not appear to be preferentially partitioned into either liquid. The alkalis show contrasting affinities with $\mathrm{Na}_{2} \mathrm{O}$ concentrated in the ocellus and $\mathrm{K}_{2} \mathrm{O}$ preferring the matrix. These features are best illustrated for each element by plots of its concent in the ocelli

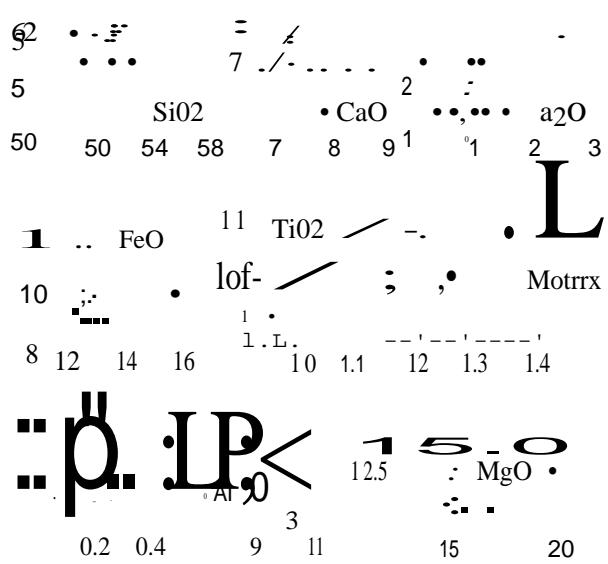

FIG. 4.-Plot of concentration of all oxides in the ocelli (vertically) against concentration in the matrices (horizontally). The diagonal lines are at $45^{\circ}$ and indicate no preferential partitioning of elements. Ali iron is plotted as FeO.

against its content in the matrix (fig. 4). It may be inferred from figure 4 that the concentrations of $\mathrm{FeO}$ and $\mathrm{MgO}$ in the matrix remain constant while there are significant variations in the ocelli concentrations. This could imply a steep limb to one side of the solvus for these oxides. By the same reasoning for $\mathrm{TiO}_{2}$ and $\mathrm{SiO}_{2}$, the opposite limb may be steep. $\mathrm{K}_{2} \mathrm{O}$ appears to follow $\mathrm{SiO}_{2}$ and $\mathrm{TiO}_{2}$, while $\mathrm{Na}_{2} \mathrm{O}$ resembles $\mathrm{MgO}$ and $\mathrm{FeO}$ in figure 4. However, because of the greenschist metamorphism it is uncertain whether these analyses reflect original alkali concentrations.

We suggest the ocelli and matrix represent two distinct liquids. Their interrelationship could be due to one liquid undergoing liquid immiscibility or two liquids, derived either from completely independent sources or from a fractionating magma becoming physically mixed. If the former hypothesis were correct there ought to be a systematic relation between the compositions of ocelli and matrix, whereas; according to the latter hypothesis, co-existing compositions could be entirely random. Elsewhere (Cawthorn and Fraser, in prep.), we have discussed a statistical test for the magma mixing model and concluded that the probability of 
random magma batches producing the observed element distributions is extremely small.

One way of presenting these analyses diagrammatically is to plot them in a triangular diagram

$$
\begin{aligned}
& \mathrm{SiOrCaO}+\mathrm{MgO}+\mathrm{FeO}+\mathrm{Fe}_{2} \mathrm{O}_{3}+ \\
& \mathrm{TiO}_{2}-\mathrm{Al}_{2} \mathrm{O}_{3}+\mathrm{Na}_{2} \mathrm{O}+\mathrm{K}_{2} \mathrm{O} .
\end{aligned}
$$

The data are shown in figure 5 where they are compared with the liquid immiscibility field in which tholeiites containing ocelli plotted (Gélinas et al. 1976). The conclusion which may be drawn from this diagram is that the pairs of ocelli and matrix have a systematic chemical relationship which is very similar to that reported for other pairs of immiscible liquids. This suggests that these pairs of analyses are related by immiscibility rather than being random magma batches from two separate sources.

An important criterion for liquid immiscibility is that both liquids ought to be in equilibrium with the same minerai compositions. No primary minerais ate preserved in these rocks, if they ever existed and so this test cannot be applied directly. However, it can be seen from the analyses of Cawthorn and McCarthy (1977) that ail but one pair of samples have identical $\mathrm{Mg} / \mathrm{Fe}$ ratios suggesting that they could therefore be equilibrium liquids. If the liquids were generated by some fractionation process and then physically mixed, the $\mathrm{Mg} / \mathrm{Fe}$ ratios would almost certainly be different. While this does not prove liquid immiscibility it would be surprising if magmas from different sources which were being physically mixed had identical $\mathrm{Mg} / \mathrm{Fe}$ ratios. One pair of liquids has different $\mathrm{Mg} / \mathrm{Fe}$ ratios and so is probably not an equilibrium assemblage. It is interesting to note that for this pair, $\mathrm{TiO}_{2}$ and $\mathrm{FeO}$ are partitioned in the opposite sense from ail the other pairs again suggesting it is anomalous; and further that the tie line for this pair has a different orientation in figure 6 from ail the others. This sample bas been omitted from ail the diagrams relating to the discussion of the chemistry of these lavas.

Hughes (1977) and Philpotts (1977) have questioned the validity of one example purporting to indicate liquid immiscibility, that of Gélinas et al. (1976). While there is a large range in composition of the matrix in this example, the ocelli have almost constant composition, suggesting an unusual shape to the immiscibility solvus. (However, Rutherford et al. ( 1976) have inferred that asymmetrical loops may exist ). This criticism cannot be levelled at the data presented here as there is as big a range in the ocelli as in the matrix for ail elements. This implies a fairly symmetrical, regular shape to the immiscibility loop for these lavas. Sorne of these pairs of liquids show only small differences in composition. It may be, therefore, that the cooling magma entered the immiscibility solvus close to the consulute top of the loop.

\section{THE ORIGINAL LIQUIDS}

If these lavas indicate liquid immiscibility, it is desirable to know whether they represent immiscibility from the same liquid composition, but produced at different temperatures, or formed from a range of initial magmas. This can be tested by plotting any variation diagram. If ail the liquid pairs formed from a single magma, tie-lines on such a plot ought to have a single composition in common-that of the original magma. In figure 6 a binary plot of $\mathrm{MgO}$ and $\mathrm{SiO}_{2}$ shows that the tie-lines are ail approximately parallel. Bence, it seems that no single composition could, by exsolution, produce ail the pairs of ocelli and matrix, but that a range of liquids must have been involved. The likely compositions of the original liquid may fall in the ringed area on figure 6 , and hence contain $13-15 \% \mathrm{MgO}$ and $53-55 \% \mathrm{SiO}_{2}$. They could therefore be regarded as picritic compositions. The compositions of the ocelli are generally significantly quartz-normative (5-10\%) while those of the matrix lie close to the plane of silica oversaturation (slightly quartz- or olivine normative). Thus, the original liquid may have been rather unusual in being highly magnesian and yet quartz-normative. However, because of the greenschist facies metamorphism the analyses for alkalis may be suspect and so too much emphasis on the normative composition may be unjustified.

Other examples of ocelli occurring in magnesian-rich lavas have been reported for komatiites by Nisbet et al. (1977) and Ferguson and Currie (1972) and in picrites by Drever (1960). It may be, therefore, that such mag- 


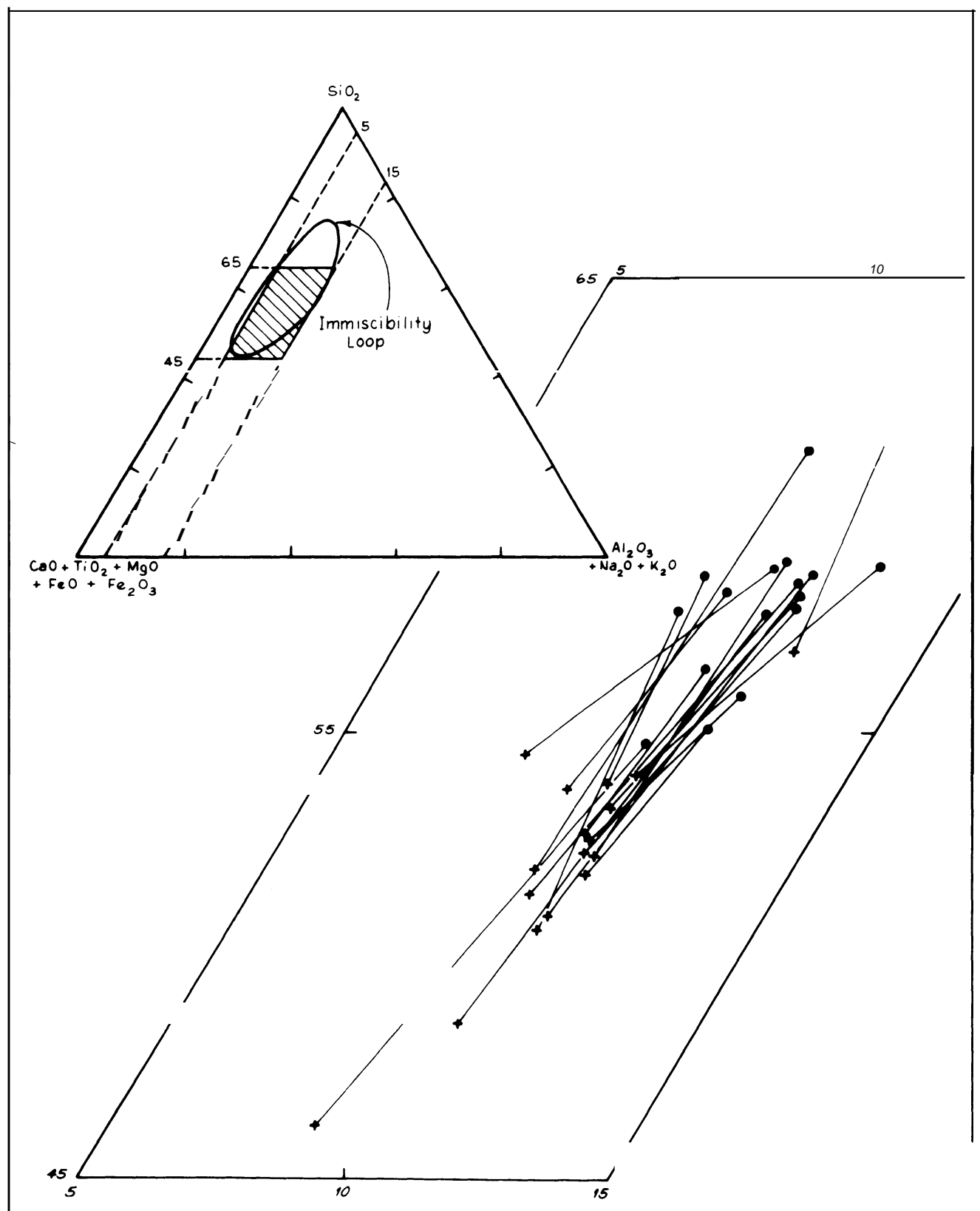

FIG. 5.-Plot of part of the triangle $\left(\mathrm{CaO}+\mathrm{TiO}_{2}+\mathrm{MgO}+\mathrm{FeO}+\mathrm{Fe}_{2} \mathrm{O}_{3}\right)-\left(\mathrm{SiO}_{2}\right\}-\left(\mathrm{Al}_{2} \mathrm{O}_{3}+\right.$ $\mathrm{Na} 2 \mathrm{O}+\mathrm{K}_{2} \mathrm{O}$ ). The shaded area of the inset shows the portion illustrated in the main diagram, and the immiscibility loop is that from Roedder (1951). Tie lines join coexisting ocelli (circles) and matrix (crosses) compositions. 


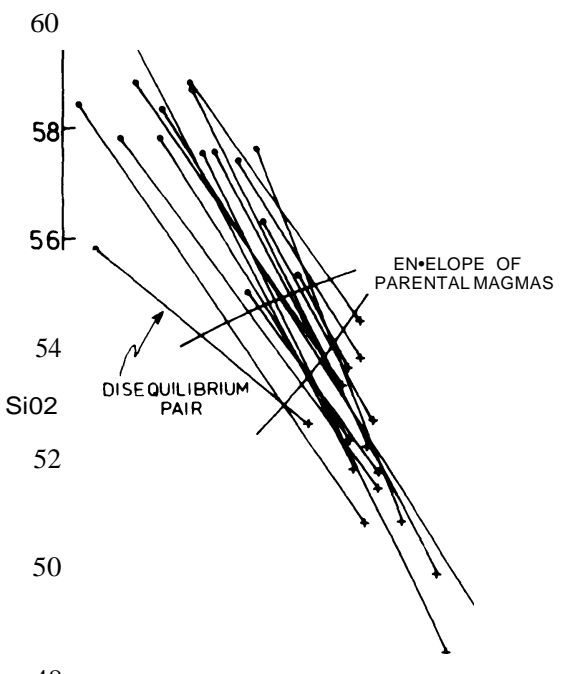

48

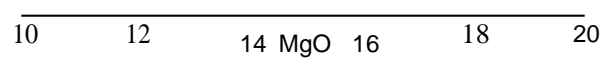

Fm. 6.-Plot of $\mathrm{MgO}$ versus $\mathrm{SiO}_{2}$ of ail pairs of analyses showing that no single original magma composition could have produced ail these pairs of liquids. One pair has different $\mathrm{Mg} /(\mathrm{Mg}+\mathrm{Fe})$ ratios and is interpreted as a disequilibrium pair (see text). An envelope of probable original magma compositions is indicated.

nesian lavas may comprise another category of magma within which liquid immiscibility may be relatively common.

\section{CONCLUSIONS}

The salient field relations indicative of liquid immiscibility observed in lavas exposed in Eagle Brick Quarry are: (a) an alternating sequence of light and dark layers, the lower contact of the light layers frequently being cuspate white the upper contact is sharp;

(b) ocelli, physically identical in appearance to material in the light layers, occur in the dark layers. The reverse never occurs;

(c) the remarkably uniform distribution of amygdales throughout both the ocelli and matrix in the lavas indicates rapid quenching. This rapid quenching negates the possibility of in situ segregation of the immiscible liquids on the scale observed. Hence, it is postulated that the separation may have occurred in a high level magma chamber during slow cooling prior to eruption.

These field relations are consistent with an origin by liquid immiscibility. Chemical data suggest sympathetic compositional variations between co-existing ocelli and matrix pairs. Preferential partitioning of elements into ocelli or matrix is always in the same sense. The compositions of these two liquids have similar characteristics to those found in other lavas showing immiscibility and to an experimentally determined immiscibility loop. The smalt differences in composition between supposedly coexisting liquids may result if the original magma is close to the consulute composition.

ACKNOWLEDGMENTS.-We are grateful to A. R. Philpotts and M. J. Rutherford for their many useful comments on this manuscript. Financial support was from C.S.l.R. (S. Africa).

\section{REFERENCES CITED}

BoTIINGA, Y., and WEILL, D. F., 1970, "Densities of liquid silicate systems calculated from partial molar volumes of oxide components": Amer. Jour. Sei., v. 269, p. 169-182.

$\longrightarrow$ _ and _ _ 1972, "The viscosity of magmatic silicate liquids: a mode! for calculation": Amer. Jour. Sei., v. 272, p. 438-475.

CAWTHORN, R. G., and McCARTHY, T. S., 1977, "Partitioning of $\mathrm{Ni}$ between immiscible picritic liquids": Earth and Planetary Sei. Letters, v. 37, p. 339-346.
DE, A., 1974, "Silicate liquid immiscibility in the Deccan Traps and its petrogenic significance": Geol. Soc. Amer. Bull., v. 85, p. 471-474.

DREYER, H. 1., 1960, "Immiscibility in the picritic intrusion at lgdlorsuitt, West Greenland": 2lst lnt. Geol. Congr., Copenhagen, Sec. 13, p. 47-58.

FERGUSON, J., and CURRIE, K. L., 1972, "Silicate immiscibility in the ancient 'basalts' of the Barberton Mountainland, Transvaal": Nature, v. 235, p. 86-89.

ÜÉLINAS, L.; BROOKS, C.; and TRZCIENSKI, W. E., 
1976, "Archean variolites-quenched irnmiscible liquids": Can. Jour. Earth Sei., v. 13, p. 210-230.

HESS, P.C.; RUTHERFORD, M.J.;GUILLEMETTE, R. N.; RYERSON, F. J.; and TUCHFELD, H. A., 1975, "Residual products of fractional crystallization of lunar magas; an experirnental study": Proc. Lunar Sei. Conf., 6, p. 895-909.

HUGHES, C. J., 1977, "Archean variolites-quenched immiscible liquids: Discussion": Can. Jour. Earth Sei., v. 14, p. 137-139.

McBIRNEY, A. R., and NAKAMURA, Y., 1974, "lmmiscibility in the late-stage magmas of the Skaergaard intrusion": Yrbk. Carnegie Instn., Washington, No. 73, p. 348-352.

NISBET, E. G.; BICKLE, M. J.; and MARTIN, A., 1977, "The matie and ultramafic lavas of the Belingwe greenstone belt, Rhodesia": Jour. Petrology, v. 18, p. 521-566.

PHILPOTTS, A. R., 1976, "Silicate liquid irnmiscibility: its probable extent and petrogenetic significance": Amer. Jour. Sei., v. 276, p. 1147-1177.

1977, "Archean variolites-quenched immiscible liquids: Discussion": Can. Jour. Earth Sei., v. 14, p. 139-144.

ROEDDER, E. 1951, "Low temperature liquid immi- scibility in the system $\mathrm{K} 20-\mathrm{FeO}-\mathrm{Al}_{2} \mathrm{O}_{3}$ Si02": Amer. Minerai., v. 36, p. 282-286.

—, and WEIBLEN, P. W., 1970, "Silicate liquid immiscibility in lunar magmas, evidenced by melt inclusions in lunar rocks": Science, v. 167, p. 641-644.

, and $\longrightarrow$, 1971, "Petrology of silicate melt inclusions, Apollo 11 and Apollo 12 and terrestrial equivalents": Proc. Lunar Sei. Conf. 2, p. 507-528. RUTHERFORD, M. J.; HESS, P. C.; RYERSON, F. J.; CAMPBELL, H. W.; and DICK, P. A., 1976, "The chemistry, origin and petrogenetic implications of lunar granite and monzonite": Proc. Lunar Sei. Conf. 7, p. 1723-1740.

TRUSWELL, J. F., 1970, "An introduction to the historical geology of South Africa": Purnel Cape Town, 167p.

WINTER, H. DE LA R., 1976, "A lithostratigraphic classification of the Ventersdorp succession": Geol. Soc. S. Afr., Trans., v. 79, p. 31-48.

WYATT, B. A., 1976,"The geology and geochemistry of the Klipriviersberg volcanics, Ventersdorp Supergroup, South of Johannesburg": Unpubl. M.Sc. thesis, Univ. Witwatersrand. 